\title{
Preparasi sel mamalia CHO-DG44 dan isolasi plasmid dari bakteri Eschericia coli DH5-alfa sebagai tahap dalam produksi protein terapeutik erythropoetin sebagai obat anemia
}

\author{
Preparation of CHO-DG44 mammal cell and plasmid isolation of Eschericia coli \\ bacteria DH5-alpha as a stage in therapeutic protein erythropoetin production as a \\ medication for anemia
}

\author{
Alfi Saadah ${ }^{1}$, Adi Santoso ${ }^{2}$, Popi Hadi Wisnu Wardhani ${ }^{2}$, Yayuk Astuti ${ }^{1}$ \\ ${ }^{1}$ Chemistry Department, Faculty of Sciences and Mathematics, UNDIP, Indonesia \\ ${ }^{2}$ Therapeutic proteins and vaccines Laboratory, Biotechnology Research Center, \\ The Indonesian Institute of Sciences, Indonesia
}

Email: alfisaadah88@gmail.com

Diterima 11 April 2020

Disetujui 2 Oktober 2020

\section{INTISARI}

Erythropoietin merupakan suatu hormon yang menstimulasi sumsum tulang untuk memproduksi sel-sel darah merah yang dibutuhkan oleh tubuh untuk membawa oksigen ke organ-organ vital. Sel CHO-DG44 nonhuman normal cell merupakan salah satu sel mamalia yang dapat digunakan untuk produksi erythropoietin. Penelitian ini bertujuan menentukan pertumbuhan optimum sel CHO-DG44 selama 12 hari, dengan menggunakan parameter densitas dan viabilitas serta menentukan karakteristik plasmid DNA bakteri E. Coli DH5 alfa hasil isolasi menggunakan metode elektroforesis yang telah sesuai untuk transfeksi ke dalam sel CHO-DG44. Hasil penelitian menunjukkan Sel CHO-DG44 memiliki viabilitas rata-rata 69,82\% untuk kultur sel CHO-DG44 tabung 1 dan 75,99\% untuk kultur sel CHO-DG44 tabung 2 dengan densitas rata-rata berturut-turut yaitu $3.130 .000 \mathrm{sel} / \mathrm{mL}$ dan $4.106 .000 \mathrm{sel} / \mathrm{mL}$. Sedangkan media kultur yang menghasilkan sel dengan viabilitas (kemampuan hidup) yang tinggi yaitu pada hari ke 4 untuk Erlenmeyer 1 dan hari ke 6 untuk Erlenmeyer 2. Hasil elektroforesis menunjukkan bahwa DNA plasmid memiliki ukuran 5954 bp dengan konsentrasi DNA sebesar $117 \mathrm{ng} / \mu \mathrm{l}$, yang sesuai dengan ukuran dan konsentrasi plasmid DNA agar dapat ditransfeksikan ke dalam sel CHO-DG44.

Kata kunci: Terapeutik Erythropoietin, isolasi plasmid, elektroforesis, DNA plasmid, anemia

\begin{abstract}
Erythropoietin is a hormone that stimulates the bone marrow to produce red blood cells needed by the human body to carry oxygen to vital organs. CHO-DG44 cells are one of the mammalian cells that can be used for the production of erythropoietin. This study aims was to determine the optimum growth of CHODG44 cells for 12 days using density and viability parameters and determine the characteristics of E. coli DH5 alpha bacterial DNA isolates using electrophoresis method which is suitable for transfection into CHO-DG44 cells. The results showed that CHO-DG44 cells had an average viability of $69.82 \%$ for media 1 and $75.99 \%$ for media 2 with a mean density of 3.130,000 cells $/ \mathrm{mL}$ and 4,106,000 cells/mL respectively. While the culture media that produced cells with high viability were on day 4 for erlenmeyer 1 and day 6 for erlenmeyer 2. From the results of electrophoresis, plasmid DNA had a size of 5954 bp with a DNA
\end{abstract}


concentration of $117 \mathrm{ng} / \mu 1$, which according to the size and concentration of plasmid DNA so that it can be transfected into CHO-DG44 cells.

Keywords: Therapeutic Erythropoietin, plasmid isolation, electrophoresis, plasmid DNA, anemia

\section{PENDAHULUAN}

Anemia atau kekurangan zat besi merupakan masalah kesehatan yang umum dijumpai di negara-negara berkembang termasuk Indonesia. Anemia erat kaitannya dengan hormon Erythropoietin (Miranda et al., 2015) yang berfungsi menstimulasi sumsum tulang belakang untuk memproduksi sel sel darah merah dalam tubuh yang selanjutnya digunakan untuk menyalurkan oksigen ke organ-organ. Hormon Erythropoietin (EPO) diproduksi oleh ginjal yang sehat. Oleh karena itu, jika ginjal sudah tidak normal, maka sel sel darah merah yang diproduksi oleh sumsum tulang menjadi sangat rendah sebagai akibat rendahnya hormon EPO yang dihasilkan oleh ginjal. Gejala anemia penderita mulai terlihat ketika fungsi ginjal hanya mencapai 20-50\% dari fungsi normal (Ma'at, 2019) .

Erythropoietin (Miranda et al., 2015) merupakan hormon yang berfungsi untuk memacu pembentukan sel-sel darah merah pada sumsum tulang (bone marrow) (Ma'at, 2019). Hormon EPO dihasilkan oleh ginjal. Upaya memproduksi EPO secara eksternal dapat dilakukan dengan menggunakan obat biologi yang diproduksi di dalam sel hidup yaitu sel mamalia CHO-DG44 (Abdelrazik \& Fouda, 2007).

Saat ini obat dapat diproduksi melalui sel mamalia secara in vitro yang sering disebut dengan obat bioteknologi yang terdiri atas obat biologi dan obat bermolekul kecil. Pembuatan obat biologi lebih rumit daripada obat bermolekul kecil. Bahkan perubahan kecil dalam proses pembuatan dapat menyebabkan perubahan signifikan dalam khasiat dan imunogenisitas. Dengan demikian, produksi obat biologis merupakan keadaan yang secara inheren tidak stabil yang memerlukan penanganan dan penyimpanan khusus (Van De Craen et al., 2012). Obat biologi hanya dapat diproduksi dalam kultur sel hidup. Oleh karena itu, biaya yang dibutuhkan untuk memproduksinya lebih mahal, terutama karena sering digunakan untuk kondisi kronis, seperti rheumatoid arthritis, dan anemia yang disebabkan oleh penyakit ginjal kronis (Brinks et al., 2011).

Penelitian ini bertujuan mengetahui preparasi kultur sel mamalia CHO-DG44 yang digunakan pada proses produksi dari obat biologis yang menghasilkan protein rekombinan erythropoietin sebagai protein terapeutik untuk mengobati anemia yang disebabkan oleh penyakit ginjal kronis. Hasil penelitian ini diharapkan akan diketahui langkah awal produksi protein terapeutik yang meliputi penanaman kultur sel CHO-DG44 dan isolasi DNA dengan metode elektroforesis. Sel CHO-DG44 dipilih karena merupakan sel standart untuk produksi dalam industri untuk memproduksi obat. Sel ini diperoleh dari kultur sel telur Hamster Tiongkok dengan nama dagang CHO-DG44 dengan nomor klon 193.2.3 (Eschbach et al., 1990).

\section{MATERI DAN METODE}

\section{Alat dan bahan}

Alat:

Mikro pipet ukuran P10, P20, P100 dan P1000, Erlenmeyer, Laminar air flow, $\mathrm{CO}_{2}$ Chamber, conical microtube, pipettor, serological pipet 25 $\mathrm{mL}, 10 \mathrm{~mL}$, dan $2 \mathrm{~mL}$, microtube $1,5 \mathrm{~mL}$, conical tube, Biologycal Safety Chamber (BSC), serological pipet $2 \mathrm{~mL}$, Mikroskop, Hemasitometer, alat sentrifugasi, freezer, cryotube, High-Speed Plasmid mini kit, Spektrofotometer DNA (GeneQuant), Spektrofotometer Nanodrop, set elektroforesis, nampan, cryogenic vials, hot plate stirer, magnetic stirer, Microwave, Timbangan, Vortex Mixer, pipet gondok. 


\section{Bahan:}

Medium OptiCHO (Thermo Fisher Scientific), Sel CHO-DG44 (Clone 193.2.3) (Thermo Fisher Scientific), L-glutamin, FBS 20\%, DMSO 10\%, Agarose 1\%, TAE 0,5x, Loading Dye, Red Gel, dan larutan EtBr, Alkohol 70\%, Tryphan blue, Satu set High-Speed Plasmid mini Kit (Geneaid), 50X TAE, Aquades.

\section{Prosedur kerja}

\section{Teknik dasar kultur sel cho-dg44}

Persiapan media yang akan digunakan sebagai tempat tumbuhnya sel yang terbuat dari campuran medium CD optiCHO $96 \%$ dan L-glutamin 4\% dalam $100 \mathrm{~mL}$ media. Medium CD optiCHO digunakan untuk kultur sel jenis suspensi, berbentuk cair dan mengandung buffer sodium bikarbonat, dan bahan aditif sodium piruvat, tidak mengandung serum, glutamin, dan antibiotik. Sedangkan L-Glutamin adalah asam amino yang dibutuhkan untuk kultur sel.

\section{Thawing sel CHO-DG44}

Penumbuhan sel dari sel beku yang dicairkan (Thawing sel) dengan cara merendamnya didalam penangas berisi air keran pada suhu ruang. Sel kemudian diencerkan ke dalam media secara perlahan karena pengenceran yang cepat dapat menyebabkan kerusakan osmotik dengan adanya dimetil sulfoksida yang terkandung dalam media. Proses penyimpanan sel yang telah dikultur dilakukan di dalam inkubator $\mathrm{CO}_{2}$ dengan suhu $37^{\circ} \mathrm{C}$ dengan kadar $\mathrm{CO}_{2} 5 \%$ ditambahkan aquades pada inkubator untuk pertukaran $\mathrm{CO}_{2}$ dan agar inkubator tidak terlalu panas serta menjaga kelembaban.

\section{Passage cell}

Pemindahan sel ke dalam media baru. Kemudian dilakukan perhitungan sel menggunakan alat hemositometer menggunakan tryphan blue $0,4 \%$ dengan perbandingan $1: 1$ yaitu $25 \mu 1$ sel CHO-DG44 dan $25 \mu 1$ tryphan blue. Jika viabilitas sel $80-100 \%$ maka sel konfluen. Sel yang memiliki kecepatan pertumbuhan tertinggi dalam Erlenmeyer akan mendominasi pertumbuhan sehingga menghasilkan keseragaman genotip dan fenotip dalam suatu populasi (Birch \& Arathoon, 1990). Selanjutnya dilakukan Cryopreservation yaitu proses dimana organel, sel, jaringan, matriks ekstraselular, organ atau konstruksi biologis lainnya yang rentan terhadap kerusakan yang disebabkan oleh kinetika kimia jika tidak disimpan pada suhu yang sangat rendah (biasanya $-80^{\circ} \mathrm{C}$ menggunakan karbon dioksida padat atau $-196^{\circ} \mathrm{C}$ menggunakan nitrogen cair). Pembekuan sel yang optimal juga akan mempengaruhi jumlah maksimal sel viabel.

\section{Assesing product (AP)}

Sel CHO-DG44 dikeluarkan dari dalam inkubator. Kemudian dibersikan dengan tisu beralkohol dan dimasukkan ke dalam Biological Safety Chamber. $1 \mathrm{~mL}$ sel tersebut dimasukkan ke dalam microtube. Ambil $25 \mu \mathrm{L}$ sel dari microtube menggunakan mikro pipet dan dicampurkan dengan tryphan blue. Kemudian ambil $25 \mu \mathrm{L}$ letakkan pada Hemasitometer

Selanjutnya diamati dengan mikroskop dan dihitung jumlah selnya menggunakan hand counter. Cara menghitung sel pada proses Assesing product yaitu, mengambil $1 \mathrm{~mL}$ sel dari erlemeyer dengan serological pipet $2 \mathrm{~mL}$ masukkan ke dalam microtube. Kemudian menyiiapkan tryphan blue $25 \mu \mathrm{L}$ ke dalam micro tube menggunakan micro pipet. Kemudian mengambil $25 \mu \mathrm{L}$ sel dari microtube menggunakan micro pipet. Lalu, campurkan dengan tryphan blue. Kemudian ambil $25 \mu \mathrm{L}$ campuran letakkan pada Hemasitometer. Dan menghitung sel menggunakan hand counter

Jumlah sel yang akan digunakan untuk Assesing Product yaitu $9.000 .000 / 30 \mathrm{~mL}$ yang dibagi menjadi 2, yaitu:

1. Erlenmeyer $13,73 \mathrm{~mL}$ sel $+26,3 \mathrm{~mL}$ Media

2. Erlenmeyer $23,95 \mathrm{~mL}$ sel $+26,05 \mathrm{~mL}$ Media Sel dihitung setiap 2 hari sekali selama 8 Hari untuk menghitung nilai densitas dan viabilitas sel CHO DG44 dengan rumus:

$$
\begin{aligned}
& \text { Densitas cell } / \mathrm{mL}=\frac{\text { jumlah sel hidup }}{\mathbf{4}} \times 2 \times 10^{4} \\
& \text { Viabilitas }=\frac{\text { jumlah sel hidup }}{\text { jumlah sel total }} \% \quad \text { (Ma'at, 2019) }
\end{aligned}
$$




\section{Isolasi plasmid dengan metode elektroforesis (analisa kualitatif)}

\section{Sample preparation/harvesting}

Untuk mempersiapkan sampel yang akan diekstraksi, pertama pindahkan 1,5 mL sel bakteri Eschericia Coli DH5-alfa ke dalam microtube kemudian disentrifugasi selama 5 menit dengan kecepatan $12.000 \mathrm{rpm}$ dengan suhu $4^{\circ} \mathrm{C}$.

\section{Re-suspension}

Tahap ini berfungsi untuk memisahkan plasmid dari bakteri E. Coli DH5-alfa yang mengandung DNA restriksi untuk transfeksi dari komponenkomponen lainnya. Pemisahan dilakukan dengan menambahkan PD1 buffer $200 \mu 1$ ke dalam tabung berisi sel bakteri. PD1 buffer ini mengandung RNAse A yang akan melisiskan sel bakteri dengan cara meningkatkan osmositas di dalam sel bakteri sehingga menyebabkan air akan masuk ke dalam sel sehingga sel bakteri akan membengkak dan lama kelamaan pecah.

\section{Cell lysis}

Cell lysis dilakukan dengan menggunakan PD2 buffer $200 \mu 1$ yang berfungsi untuk melarutkan pellet sel yang terbentuk pada Re-suspension. Selain itu berfungsi untuk melisis membran sel, melarutkan protein, dan mendisosiasi kompleks nukleoprotein dari nukleotida sehingga DNA dapat keluar dari inti sel dan terpisahkan dari komponen biomolekul pengotor lainnya.

\section{Neutralization}

Tahap Neutralization dilakukan dengan menambahkan larutan PD3 300 $\mu 1$ ke dalam larutan untuk menetralisasi larutan dari Cell Lysis. Kemudian digoyang 10 kali dengan pelanpelan agar DNA tidak rusak dan agar larutan homogen. Kemudian disentrifuge selama 5 menit dengan kecepatan $12.000 \mathrm{rpm}$ pada suhu $4^{\circ} \mathrm{C}$.

\section{DNA binding}

DNA yang telah keluar dari dalam inti sel setelah tahap dua (cell lysis) selanjutnya harus dipisahkan dari molekul pengotor lainnya. Tahap binding dilakukan dengan menempatkan PD column ke dalam collection tube 2 berfungsi untuk memisahkan presipitan DNA yang terbentuk setelah dilakukan sentrifugasi dengan supernatan.

\section{DNA wash}

Tahap ini dilakukan untuk melarutkan sisa-sisa garam (residual salt) serta sisa protein dan RNA yang terdegradasi yang mungkin terdapat pada membran dalam PD column (Kitt, 2001). Pencucian residu protein dan RNA ini dilakukan dengan penambahan $400 \mu \mathrm{l}$ buffer ke dalam PD column yang mengandung garam chaotropic (Garam Guanin Tiosianat) yang akan melarutkan residu protein dan RNA tanpa melarutkan kembali pellet DNA yang terdapat dalam membran PD column (Kitt, 2001). Kemudian di sentrifuge selama 5 menit dengan kecepatan $12.000 \mathrm{rpm}$. Setelah itu dilakukan pencucian dengan menggunakan wash buffer $600 \mu$ l yang mengandung etanol yang berfungsi untuk melarutkan residu garam yang mungkin terdapat pada PD column dan permukaan pellet DNA (Dhaliwal et al., 2013) kemudian dilakukan sentrifuge kembali selama 5 menit dengan kecepatan 12000 rpm. PD column dituang kembali ke dalam collection tube $2 \mathrm{ml}$. Kemudian disentrifugasi kembali selama 5 menit dengan kecepatan $12000 \mathrm{rpm}$.

\section{DNA elution}

Tahap DNA elution dilakukan dengan melarutkan kembali pellet DNA yang terdapat dalam membran dengan menggunakan $50 \mu \mathrm{l}$ elution buffer yang mengandung $10 \mathrm{mM}$ Tris- $\mathrm{HCl}$ (pH 8.5), garam, dan EDTA. Larutan DNA yang diperoleh dalam microcube kemudian disentrifugasi kembali selama 5 menit dengan kecepatan 12000 rpm selanjutnya disimpan pada suhu $-20^{\circ} \mathrm{C}$ untuk mencegah terjadinya kerusakan DNA sebelum dilakukan analisis.

\section{Elektroforesis}

Setelah didapatkan DNA hasil ekstraksi kemudian dilakukan elektroforesis dengan cara memasukkan media agarose $1 \%$ dengan cara menimbang agarose powder (Analytical grade) 1 
gram. Kemudian melarutkan agarose powder ke dalam larutan buffer TAE $0,5 \mathrm{X}$ hingga volume $100 \mathrm{ml}$. Larutan agarose dididihkan hingga larut sempurna. Siapkan cetakan gel agarose, letakkan selotip ditiap ujung cetakan gel agarose. Lalu Pasang sisir elektroforesis di salah satu ujung cetakan gel agarose dengan posisi hampir menyentuh dasar cetakan. Larutan agarose dihomogenkan kemudian dituang ke dalam cetakan gel agarose, kmudian biarkan hingga larutan berubah menjadi gel padat. Gel agarose $1 \%$ diletakkan ke dalam cetakan alat elektroforesis. Kemudian loading dye orange dimasukkan ke dalam microtube dengan perbandingan 1:6. Selanjutnya media agarose dimasukkan ke dalam cetakan elektroforesis (tuang hingga \pm setengah sisir), setelah padat, letakkan cetakan ke dalam elektroforesis. Lalu masukkan TAE 0,5X (for running) sebagai penstabil DNA yang akan dielektroforesis serta menjaga kondisi $\mathrm{pH}$ dan memungkinkan adanya aliran listrik dari ion-ion yang terkandung di dalamnya hingga cetakan agarose tenggelam. Selanjutnya semua sampel $(5 \mu 1$ DNA hasil $+5 \mu 1$ air $+2 \mu$ l loading dye, $2 \mu 1$ loading dye + DNA marker $3 \mu 1$ serta $2 \mu 1$ loading dye $+3 \mu 1$ positif kontrol) dimasukkan ke dalam masing-masing lubang. Sampel-sampel tersebut dimasukkan dengan tujuan agar terjadi migrasi oleh fragmenfragmen DNA yang bermuatan negatif ke elektoda positif pada saat elektroforesis. Dilanjutkan dengan menyalakan alat dan running elektroforesis, hingga terbentuk warna orange yang bermigrasi ke bagian bawah ( \pm 1 jam). TAE 0,5X dibuang dari cetakan kemudian cetakan dimasukkan ke dalam larutan EtBr, hingga berwarna merah. Hasil running diamati dibawah sinar UV.

\section{Analisis kuantitatif DNA}

DNA hasil isolasi selanjutnya dianalisis secara kuantitatif dengan menggunakan spektrofotometer GeneQuant. Analisis ini dilakukan dengan mengukur absorbansi larutan DNA pada pada $\lambda 260 \mathrm{~nm}$ dan pada $\lambda 280 \mathrm{~nm}$. Hasil absorbansi pada kedua panjang gelombang kemudian dibandingkan untuk melihat kemurnian DNA hasil ekstraksi.

\section{HASIL DAN PEMBAHASAN}

\section{Kultur Sel}

Hasil pengamatan terhadap masa hidup dari sel (Viabilitas) dan banyaknya sel (densitas) mulai dari proses thawing, passage cell, cryopreservation, dan assesing productivity. Jika viabilitas sel $80-100 \%$ maka sel konfluen. Assesing productivity (AP) yang telah dilakukan bertujuan untuk melihat produksi atau pertumbuhan sel serta viabilitas sel selama 8 hari. Hal ini dikarenakan sel CHO-DG44 yang mampu hidup dalam medium kultur hanya sampai hari ke8. Hasil assesing productivity yang diperoleh selama 8 hari dengan perbesaran $10.000 x$ menggunakan mikroskop cahaya dapat dilihat pada Gambar 1 dan 2. Hasil assesing productivity dilakukan perhitungan sel untuk menghitung nilai densitas dan viabilitas sel CHO DG44. Hasil perhitungan densitas dan viabilitas dapat dilihat pada Tabel 1.
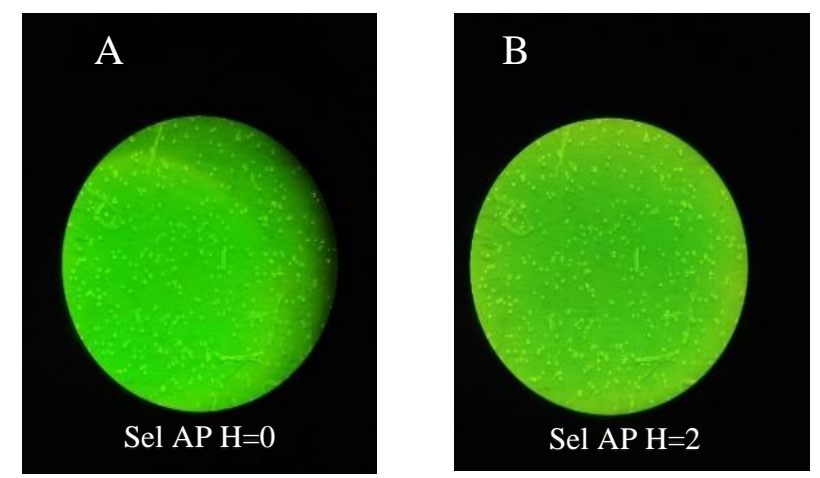

Gambar 1. Hasil Assesing Productivity hari ke 0 dengan densitas $2410000 \mathrm{sel} / \mathrm{mL}$ (a) dan hasil Assesing Productivity hari ke 2 dengan densitas 2455000 $\mathrm{sel} / \mathrm{mL}$ (b)
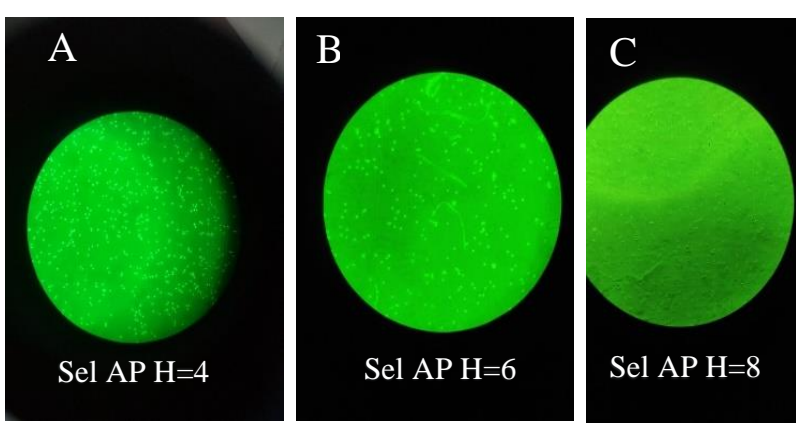

Gambar 2. Hasil Assesing Productivity hari ke 4 dengan densitas $5210000 \mathrm{sel} / \mathrm{mL}$ (a), hasil Assesing Productivity hari ke 6 dengan densitas 5040000 sel/mL (b), hasil Assesing Productivity hari ke 8 dengan densitas $535000 \mathrm{sel} / \mathrm{mL}$ (c) 
Tabel 1. Hasil Perhitungan Densitas dan Viabilitas Sel CHO-DG44

\begin{tabular}{|c|c|c|c|c|}
\hline $\begin{array}{c}\text { Sampel } \\
\text { CHO-DG44 }\end{array}$ & \multicolumn{2}{|c|}{ Erlenmeyer 1} & \multicolumn{2}{|c|}{ Erlenmeyer 2} \\
\hline Hari ke- & $\begin{array}{l}\text { Densitas } \\
\text { (sel/mL) }\end{array}$ & $\begin{array}{c}\text { Viability } \\
(\%)\end{array}$ & $\begin{array}{l}\text { Densitas } \\
\text { (sel/mL) }\end{array}$ & $\begin{array}{c}\text { Viability } \\
(\%)\end{array}$ \\
\hline 0 & 2410000 & $97,50 \%$ & 2275000 & $95,10 \%$ \\
\hline 2 & 2455000 & $92,80 \%$ & 2030000 & $95,30 \%$ \\
\hline 4 & 5210000 & $98,80 \%$ & 5335000 & $94,25 \%$ \\
\hline 6 & 5040000 & $60 \%$ & 10865000 & $95,30 \%$ \\
\hline 8 & 535000 & $0 \%$ & 25000 & $0 \%$ \\
\hline
\end{tabular}

Tabel 1 menunjukkan bahwa jumlah sel CHODG44 yang mampu hidup dalam medium kultur secara konfluen yaitu hingga hari ke 4 untuk erlenmeyer 1 dan hari ke 6 untuk erlenmeyer 2 . Dasar penggunaan erlenmeyer 1 dan 2 tersebut adalah membandingkan 2 media kultur untuk Assesing productivity selama masa penumbuhan. Tabel 1 menunjukkan bahwa media kultur menghasilkan sel dengan viabilitas (kemampuan hidup) yang tinggi pada hari ke 4 untuk Erlenmeyer 1 dan hari ke 6 untuk Erlenmeyer 2. Hal ini terjadi karena pada hari ke-4 dan ke-6 terjadi pertumbuhan optimum sel dan nutrisi dalam media kultur mencukupi untuk pertumbuhan optimum sel. Selanjutnya morfologi dari sel CHO-DG44 yang diamati adalah berbentuk sel limfoblast (Gambar 3). Sel limfoblast merupakan sel-sel yang berbentuk bulat dan biasanya tumbuh di medium suspensi tanpa melekat ke permukaan. Dilihat dari morfologi sel yang terlihat pada hemositometer dan juga medium yang digunakan pada kultur sel merupakan medium suspensi. Sel limfoblast biasanya tumbuh di medium suspensi.

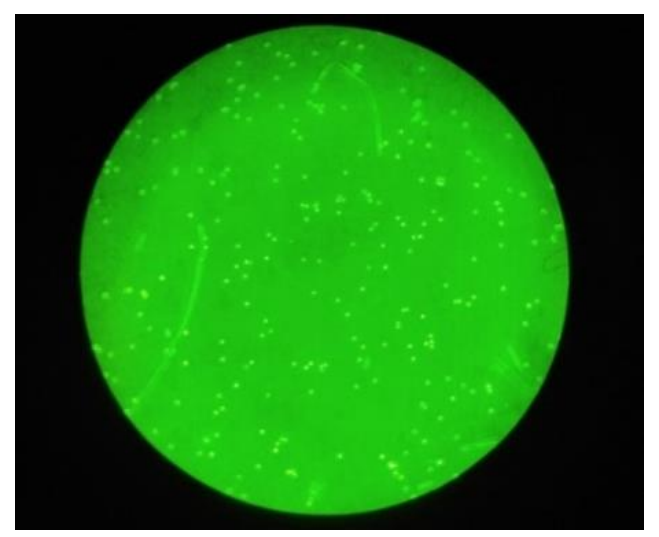

Gambar 3. Morfologi sel hasil eksperimen berbentuk limfoblas perbesaran $10.000 \mathrm{x}$
Kultur sel dapat digunakan dalam teknik rekombinan protein untuk memproduksi protein terapeutik erythropoetin yang berguna sebagai obat anemia pada penderita gagal ginjal kronis ataupun kanker. Ginjal yang tidak normal, tidak bisa memproduksi cukup EPO. Akibatnya sumsum tulang hanya memproduksi sedikit sel darah merah. Erythropoietin (EPO) berfungsi menstimulasi sumsum tulang untuk memproduksi sel-sel darah merah yang dibutuhkan untuk membawa oksigen ke organ-organ vital karena protein terapeutik tersebut merangsang pembentukan sel darah merah di dalam ginjal (Marks, 2015).

\section{Pemisahan dan identifikasi DNA plasmid dari bakteri E. Coli DH5 alfa}

Tahap ini bertujuan untuk untuk memisahkan, membuktikan bahwa plasmid yang akan ditransfeksikan pada sel CHO-DG44 benar-benar ada, dan memurnikan fragmen DNA (kualitatif) selain itu untuk mengetahui ukuran dan bentuk dari suatu partikel DNA (kuantitatif) agar dapat ditransfeksikan ke dalam sel CHO-DG44. Metode yang digunakan berturut-turut adalah elektroforesis dan spektrofotometri nanodrop. Prinsip yang digunakan berturut-turut adalah berdasarkan atas ukuran (berat molekul) dan struktur fisik molekulnya serta pengukuran absorbansi untuk menghitung konsentrasi DNA. Penglisisan sel menggunakan high speed plasmid mini kit (Geneaid). Ekstraksi ini berprinsip pada pelisisan sel untuk mengeluarkan DNA dari inti sel dan pemisahan DNA dari komponen biomolekul lain yang terdapat dalam sel. 


\section{Pemisahan DNA plasmid dari bakteri E. Coli DH5 alfa dengan metode elektroforesis}

Analisa ini dilakukan dengan metode elektroforesis gel agarose. Prinsip dari metode elektroforesis secara umum adalah pergerakan DNA di bawah pengaruh medan listrik. DNA pada strukturnya memiliki gugus fosfat sehingga DNA bermuatan negatif dan bersifat polar. Oleh karenanya ketika DNA diletakan dalam anoda dari suatu sistem elektroforesis maka DNA akan bergerak menuju kutub positif. Agarose gel berperan sebagai media tempat bergeraknya DNA sekaligus sebagai penyaring molekuler yang akan memisahkan DNA berdasarkan ukurannya yang diukur dengan banyaknya pasang basa (base pair). Dalam strukturnya agarose tampak seperti kertas saring yang memiliki pori. Semakin besar konsentrasi agarose yang digunakan berarti ukuran pori semakin kecil sehingga baik digunakan untuk memisahkan DNA yang berukuran kecil. Sementara itu agarose dengan konsentrasi rendah baik digunakan untuk memisahkan DNA yang berukuran besar. Adapun konsentrasi DNA yang umumnya digunakan dalam elektroforesis gel agarose adalah $0,8-2 \%$ (Ghatak et al., 2013).

Kualitas DNA dapat dilihat dari pola pergerakan DNA hasil elektroforesis di bawah sinar UV. Agar pola pergerakan DNA dapat terlihat di bawah sinar UV digunakan berbagai macam pewarna yang dapat berpendar di bawah sinar UV. Pewarna yang umum digunakan adalah ethidium bromide (EtBr) (Gambar 4) karena mampu menghasilkan gambar yang paling terang di bawah sinar UV meskipun senyawa ini bersifat karsinogenik (̌̌eha et al., 2002).

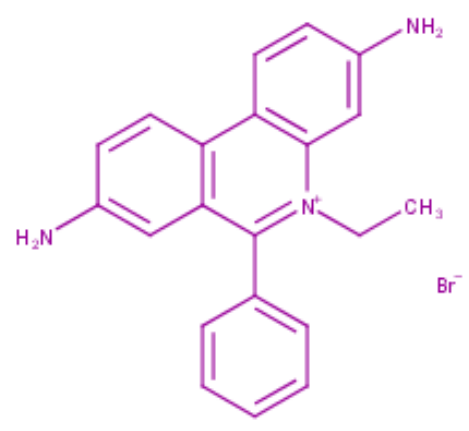

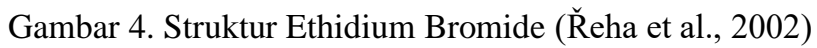

DNA dikatakan memiliki kualitas yang baik apabila menghasilkan pola elektroforesis yang konsisten dan tidak buram. Sementara itu apabila pola hasil elektroforesis buram maka dikatakan bahwa kualitas DNA kurang begitu baik. Sampel yang dimasukkan ke dalam lubang gel berisi $5 \mu 1$ DNA hasil $+5 \mu 1$ air $+2 \mu 1$ loading dye, $2 \mu 1$ loading dye + DNA marker $3 \mu 1$ serta $2 \mu 1$ loading dye $+3 \mu 1$ kontrol positif. Hasil elektroforesis sampel DNA yang diperoleh dapat dilihat pada Gambar 5.

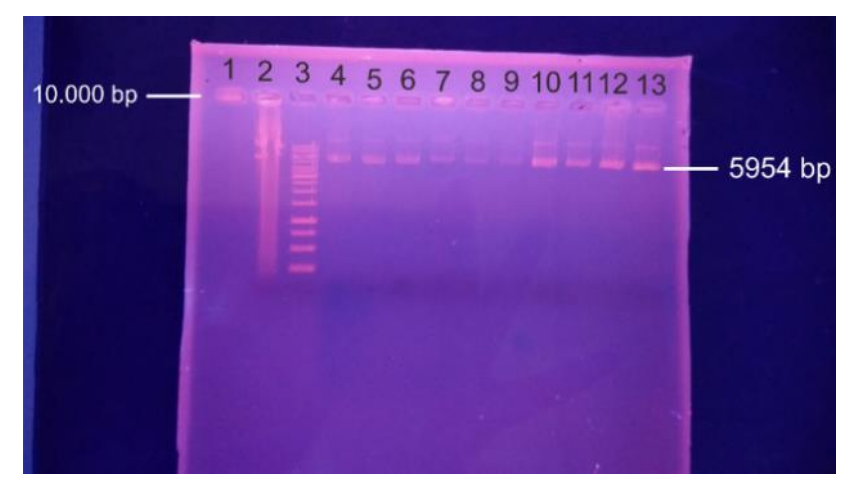

Gambar 5. Hasil elektroforesis DNA Plasmid sel bakteri E. Coli DH5-alfa

Sampel yang dimasukkan ke dalam lubang gel $4,5,6,7,8,9,11,12$, dan 13 adalah berisi $5 \mu 1$ DNA hasil high-speed plasmid mini kit $+5 \mu 1$ air $+2 \mu 1$ loading dye, sedangkan pada lubang 1 merupakan DNA Ladder 10.000 bp serta lubang gel 2 dan 3 adalah marker (DNA Ladder 100 bp Geneaid) yang berisi $2 \mu$ l loading dye + DNA marker $3 \mu 1$ serta $2 \mu 1$ loading dye $+3 \mu 1$ positif kontrol. Plasmid target ada pada lubang gel 4, 5, $6,7,8,9,10,11,12$ dan 13.

Hasil elektroforesis dapat dilihat dibawah sinar UV dibandingkan dengan letak DNA ladder 10.000 bp menunjukkan bahwa DNA plasmid sel bakteri E. Coli DH5-alfa mampu mencapai ukuran 5954 bp yang sesuai dengan ukuran plasmid DNA untuk transfeksi dan menghasilkan pola elektroforesis agak buram yang berarti DNA yang didapatkan tidak terlalu murni.

\section{Analisis kuantitatif DNA plasmid}

Analisis kuantitatif DNA dilakukan dengan menggunakan metode spektrofotometri. Analisa dilakukan untuk menentukan konsentrasi dan kemurnian DNA hasil ekstraksi. Analisis 
dilakukan dengan mengukur absorbansi larutan DNA pada $\lambda_{260} \mathrm{~nm}$ yang merupakan pita serapan maksimum DNA akibat keberadaan sistem terkonjugasi pada basa nitrogen DNA dan absorbansi pada $\lambda_{280} \mathrm{~nm}$ yang merupakan pita serapan pengotor seperti protein. Kemurnian diukur dengan membandingkan absorbansi pada $\lambda_{260}$ dan $\lambda_{280}$. DNA dikatakan murni apabila perbandingan absorbansi $\frac{\lambda \mathbf{2 6 0}}{\lambda \mathbf{2 8 0}}$ berada pada range 1,8-2,0. Apabila berada di atas atau di bawah range tersebut maka DNA hasil ektraksi dikatakan kurang murni (Permenter et al., 2015). Hasil pengukuran dapat dilihat pada Tabel 2.

Tabel 2. Hasil pengukuran konsentrasi Larutan DNA hasil ekstraksi menggunakan spektrofotometer nano.

\begin{tabular}{cc}
\hline Panjang Gelombang $(\lambda)$ & Absorbansi $(\mathrm{A})$ \\
\hline 230 & 0,054 \\
260 & 0,047 \\
280 & 0,027 \\
320 & 0 \\
\hline
\end{tabular}

Hasil pengukuran dapat diketahui bahwa tingkat kemurnian DNA $\left(\frac{\boldsymbol{\lambda 2 6 0}}{\boldsymbol{\lambda 2 8 0}}\right)$ adalah 1,714 dengan konsentrasi $117 \mathrm{ng} / \mu \mathrm{l}$. Meskipun perbandingan absorbansi $\frac{\lambda \mathbf{2 6 0}}{\mathbf{2 2 8 0}}$ tidak berada pada range 1,8-2,0. Akan tetapi, DNA masih dapat digunakan untuk transfeksi karena memiliki konsentrasi lebih dari $100 \mu$ l yang mana bertujuan untuk meningkatkan efisiensi ligasi pada saat dilakukan transfeksi (Ma'at, 2019).

\section{SIMPULAN}

Kultur sel mamalia CHO-DG44 merupakan salah satu cara yang dapat digunakan untuk memproduksi protein terapeutik erythropoetin. Sel CHO-DG44 memiliki viabilitas rata-rata $69,82 \%$ untuk media 1 dan $75,99 \%$ untuk media 2. Dengan densitas rata-rata $3.130 .000 \mathrm{sel} / \mathrm{mL}$ untuk media 1 dan $4.106 .000 \mathrm{sel} / \mathrm{mL}$ untuk media 2 dimana media kultur yang menghasilkan sel dengan viabilitas (kemampuan hidup) yang tinggi yaitu pada hari ke 4 untuk erlenmeyer 1 dan hari ke 6 untuk erlenmeyer 2. Hasil elektroforesis DNA Plasmid memiliki ukuran 5954 bp dengan konsentrasi DNA sebesar $117 \mathrm{ng} / \mu \mathrm{l}$, yang mana sesuai dengan ukuran dan konsentrasi plasmid DNA agar dapat ditransfeksikan ke dalam sel CHO-DG44.

\section{UCAPAN TERIMA KASIH}

Penulis mengucapkan terima kasih kepada Lembaga Ilmu Pengetahuan Indonesia yang telah mendanai riset ini.

\section{KEPUSTAKAAN}

Abdelrazik N, Fouda M. 2007. Once weekly recombinant human erythropoietin treatment for cancer-induced anemia in children with acute lymphoblastic leukemia receiving maintenance chemotherapy: A randomized case-controlled study. Hematology DOI: $10.1080 / 10245330701521572$

Birch JR, Arathoon R. 1990. Suspension culture of mammalian cells. Bioprocess technology 10: $251-270$

Brinks V, Jiskoot W, Schellekens H. 2011. Immunogenicity of therapeutic proteins: The use of animal models. Pharmaceutical Research. DOI: 10.1007/s11095-011-05235

Dhaliwal RS, Kitchell BE, Ehrhart EJ, Valli VE, Dervisis NG. 2013. Clinicopathologic significance of histologic grade, Pgp, and p53 expression in canine lymphoma. Journal of the American Animal Hospital Association. DOI: 10.5326/JAAHA-MS5843

Eschbach JW, Downing MR, Egrie JC, Browne JK, Adamson JW. 1990. USA Multicenter Clinical Trial with Recombinant Human Erythropoietin (Amgen). Contributions to Nephrology 160-165. DOI: $10.1159 / 000417892$

Ghatak S, Muthukumaran RB, Nachimuthu SK. 2013. A simple method of genomic DNA extraction from human samples for PCRRFLP analysis. Journal of Biomolecular Techniques. DOI: 10.7171/jbt.13-2404-001

Kitt D. 2001. Extraction of DNA from Whole Blood and White Blood Cells. 
Ma'at S. 2019. Teknik Dasar Kultur Sel. Pusat Penerbitan dan Percetakan Unair (AUP)

Marks L V. 2015. The lock and key of medicine: Monoclonal antibodies and the transformation of healthcare. . DOI: 10.1093/jhmas/jrv044

Miranda EAC, Carvajal JFM, Baena OJR. 2015. Effect of the fuels glycine, urea and citric acid on synthesis of the ceramic pigment $\mathrm{ZnCr} 2 \mathrm{O} 4$ by solution combustion. Materials Research. DOI: 10.1590/1516-1439.019915

Řeha D, Kabeláč M, Ryjáček F, Sponer J, Šponer JE, Elstner M, Suhai S, Hobza P. 2002. Intercalators. 1. Nature of stacking interactions between intercalators (ethidium, daunomycin, ellipticine, and 4',6-diaminide2-phenylindole) and DNA base pairs. Ab initio quantum chemical, density functional theory, and empirical potential study. Journal of the American Chemical Society. DOI: $10.1021 / \mathrm{ja} 011490 \mathrm{~d}$

Van De Craen B, Declerck PJ, Gils A. 2012. The Biochemistry, Physiology and Pathological roles of PAI-1 and the requirements for PAI1 inhibition in vivo. Thrombosis Research. DOI: 10.1016/j.thromres.2012.06.023 